\title{
Віталій Терлецький
}

\section{АРИСТОТЕЛЕВА ТЕОРІЯ ЧАСУ У СВІТЛІ ФЕНОМЕНОЛОГІЧНОЇ ТРАДИЦІї}

Вчення Аристотеля про час віддавна було й досі залишається хрестоматійним сюжетом у рамцях його натурфілософських поглядів. Воно досить часто й широко розглядається істориками науки, досліджується фахівцями з античної філософії, тлумачиться видавцями й перекладачами Аристотелевих праць. Останнім часом йому було присвячено низку спеціальних монографічних досліджень, що мали на меті всебічний аналіз цього поняття в Стагірита як по відношенню до попередніх теорій часу, так і в контексті цілісності власне Аристотелевого філософського вчення. Тож зміст цього сюжету, хід думки в ньому та спектр його витлумачень постають хай якими, але, певно, не маловідомими й не малодослідженими.

Утім, доводиться констатувати й той факт, що переважна більшість таких різнопланових розвідок зовсім обходять мовчанням певну лінію традиції в трактуванні темпоральної проблематики Аристотеля ${ }^{1}$. Йдеться про традицію феноменологічного прочитання Філософа, яка виникла, вочевидь, не 3 історичних мотивів, але при цьому неабияк продовжує впливати на сучасні філософські дослідження й історикофілософські студії. Мета пропонованої розвідки полягає в актуалізації доробку прихильників цього своєрідного способу поводження з класичним текстом минулого й у виявленні його специфічності. Для цього доречно розпочати з позиції самого Аристотеля, відтворивши їі у вигляді спочатку послідовного синопсису головних змістових ліній трактату про час, а потім як певне ціле (1). Далі слід зосередитися на тому, в який спосіб і в якому ракурсі представники феноменології або близькі до неї дослідники інтерпретують головні змістові моменти трактату; при цьому зображення континуальності, відповідно, наступності серед інтерпретаторів теж відіграє не останню роль (2). Нарешті, варто увиразнити своєрідність цієї традиції тлумачення, що, можливо, допоможе оцінити ії потенціал і результативність (3).

\section{1}

Задля полегшення орієнтації в подальшому викладі доцільно синоптично оглянути зміст трактату Аристотеля про час, що викладений у гл. 10-14, кн. IV «Фізики».

\section{(C) В. Терлецький, 2015}

${ }^{1}$ Але $\epsilon$ й щасливі винятки, прикладом чого може слугувати дослідження О.Г. Чернякова [Черняков, 2001]. 
У гл. 10, яка, вочевидь, виконує роль вступу до проблематики часу, Аристотель спершу розглядає проблеми чи «апорії», які виникають у зв'язку з питанням про сутність часу $(217 \mathrm{~b} 32-218 \mathrm{a} 30)^{2}$, потім викладає погляди попередників на природу часу (218a30-b9), нарешті, переходить до посутнього розгляду цього феномена та висуває тезу: час «не є рухом» (218b19).

Гл. 11, продовжуючи попередній виклад, він стверджує, що хоча час і не є рухом, але він і не $\epsilon$ без руху. Між часом і рухом (зміною) наявний якийсь внутрішній зв'язок (218b21-219a10). Але час виявляється навіть залежним від руху, що обгрунтовується через безперервність (континуальність) величини, руху й, відповідно, часу (219a10-14). Далі мовиться про «перед і після», які стосуються місця, руху й також часу (219a14-21) $)^{3}$. В усвідомленні часу вирішальну роль відіграє розмежування передшого й наступного (219a22-b1). Висувається дефініція часу «як числа руху відносно передшого й наступного» (219b1-2). Зв'язок руху й часу уточнюється далі на підставі поняття «число»; розмежування двох значень «числа» (219b2-9). Аналітика «тепер» як базового моменту часу, дискусія про тотожність і відмінність «тепер» (219b9-33). Взаємозалежність «тепер» і часу (219b33-220a4). Однак час і «тепер» залежать від руху й рухомого сущого (220a4-24). Короткий підсумок дотеперішнього розгляду з повторенням дефініції часу та наголошенням на його безперервності (220а24-26).

У продовження головного викладу в гл.12 спершу зазначається, як треба розуміти найменші числа й найменші величини (220a27-32). Далі Аристотель показує, чому час $\epsilon$ великим/малим і тривалим/коротким, але не $\epsilon$ швидким і повільним (220a32-b5). Наступне міркування стосується проблеми тотожності й відмінності часу: як цілісний він тотожний, а як передший і наступний він відмінний (220b5-14). На підставі взаємного визначення руху й часу висувається теза про обопільність вимірювання: час вимірює рух і рух вимірює час (220b14-32). Положення «бути в часі» може означати: 1) бути охопленим часом і 2) бути виміряним часом (220b32221a26). Вплив часу: час як причина занепаду сущого; розрізнення часового $\mathrm{i}$ вічного (221a26-b7). Час є не лише мірою руху, а й мірою спокою (221b7-23). Буття в часі й темпоральні модальності сущого (221b23-222a9).

Гл. 13. починається із розрізнення двох значень «тепер»: 1) як «межі часу», що пов'язує минуле з майбутнім, 2) як [чогось] близького до певного часу (222a10-24). Аналіз темпоральних характеристик «колись» (poté) щодо минулого і майбутнього; теза про нескінченність часу (222a24-b7). Інші характеристики часу: «щойно» (árti) застосовується до майбутнього й до минулого, а також має значення «нещодавно», коли воно близьке до теперішнього; «давно» (pálai); «раптово» (exaíphnes) (222b716). Вплив часу: час причина занепаду (222b16-27). На завершення Аристотель підсумовує попередній розгляд цієї глави (222b27-29).

Гл. 14. знову підхоплює тезу, що будь-яка зміна й усе рухоме $є$ «в часі»; два значення «передшого і наступного»: 1) «щодо віддалення від тепер» і 2) стосовно

2 Тут і надалі посилання на текст «Фізики» здійснюється за академічним виданням творів філософа [Aristoteles, 1831: p. 217-224]. Цитати з інших творів наводяться за усталеною формою.

33 огляду на багатозначність «próteron - hýsteron», які застосовуються й у просторовому (перед після), й у часовому (раніше - пізніше) значенні, і для характеристики динамічних процесів (те, що передує - те, що йде потім), а також зважаючи на можливість різного тлумачення усього цього спектру значень, у подальшому ми відтворюємо цю пару понять в залежності від контексту, але перевагу віддаємо відносно нейтральним «передше - наступне». 
минулого й майбутнього часу (222b30-223a15). Виявлення проблематичного зв'язку між часом і душею (223a16-29). Час як «число руху» стосується кожного виду руху; теза про відмінність видів руху, але нумеричну тотожність часу (223a29-b12). Мірою для вимірювання руху і часу постає рівномірний коловий рух чи коловорот небес (223b12-224a2). Коротке міркування про тотожність; положення про тотожність числа як такого й відмінність певного числа (224a2-15). Загальний висновок розгляду часу (224a15-17).

Із систематичної точки зору Аристотелів трактат про час можна поділити на п’ять пропорційно нерівних за обсягом тематичних блоків, які у свою чергу поділяються на відповідні тематичні групи. Схематично це можна відтворити так.

I. Вступ (10, 217b29-218b9): 1) апорії часу; 2) погляди попередніх мислителів на природу часу.

II Дефініція часу як «числа руху» (10, 218b9-11; 11, 219a14; 11, 219b1-9): 1) відмежування часу від руху, внутрішній зв'язок між часом і рухом, залежність часу від руху; 2) час як «число руху»; 3) пояснювальний відступ від головного викладу: вимірювання часу (12, 220b14-32; 14, 223b12-224a2); 4) окремі пояснення: про найменші числа (12, 220a27-32), про «швидке» і «повільне» (12, 220a32-b5), про тотожність і відмінність чисел і [проміжків] часів (12, 220b5-14; 14, 223a29-b12; 14 , 224a2-15).

III. Головні темпоральні елементи «тепер», «раніше», «пізніше»: 1) «раніше/пізніше» в сприйнятті часу $(11,219 \mathrm{a} 14-\mathrm{b} 1) ; 2)$ «тепер» і його стосунок до часу $(11,219 \mathrm{~b} 9-220 \mathrm{a} 24) ; 3)$ «тепер» і нескінченність часу [можливо, рання версія тексту?] $(13,222 \mathrm{a} 10-\mathrm{b} 7)$.

IV. Буття в часі та вплив часу: 1) головний виклад теми буття в часі (12, 220b32-222a9); 2) вплив часу [можливо, рання версія тексту?] (13, 222b16-27); 3) буття в часі [можливо, рання версія тексту?] (14, 222b30-223a15).

V. Співвідношення часу і душі (14, 223a16-29).

Як демонструє запропонований огляд, трактат про час постає як відносно неоднорідний текст, де не просто відстежити головну сюжетну лінію, отже, як текст, що неодмінно потребує інтерпретації.

Засновником феноменологічної інтерпретації Аристотелевого вчення про час цілком підставно можна вважати Мартина Гайдегера. Інші феноменологи, передусім сам Едмунд Гусерль, при аналізі феномена часу стояли, мабуть, ближче до його суб'єктивно зорієнтованого потрактування, що бере свій початок у «Сповіді» св. Августина. Після публікації ранніх лекційних курсів Гайдегера (до 1927р.), особливо ж у світлі низки спеціальних розвідок $з$ теми «Гайдегер - Аристотель», здійснених останніми десятиліттями, стало зрозуміло, наскільки інтенсивно німецький філософ займався філософією Стагірита вже з початку своєї академічної кар'єри. Проте на передньому плані стояла все ж проблематика «першої філософії» Аристотеля, тематика ж «другої філософії» була присутня лише в контексті першої (інтерпретація перших чотирьох глав кн. 1 «Фізики», де йдеться, власне, не стільки про фізику, скільки про ранню фазу метафізики, як питання про початки). Переключення уваги на фізику залишається не зовсім зрозумілим, якщо не зважати на ширший історичний контекст.

У доповіді «Мій шлях у феноменологію» (1963) Гайдегер ретроспективно вказує на роль дисертації Франца Брентано «Про багатоманітне значення сущого за Ари- 
стотелем» (1862) у виникненні його власної філософії, відзначаючи, що вона була «костуром і палицею моїх перших безпорадних спроб проникнути у філософію» [Heidegger, 2007: S. 93]. Як детально показує Франко Вольпі, Брентанове тлумачення Аристотеля мало надзвичайний вплив на Гайдегера аж до формулювання базової тези фундаментальної онтології про «сенс буття» [Volpi, 1978].

Не варто забувати, що в Німеччині, попри панування (нео)кантіанства, а раніше й гегеліанства, досить потужним і впливовим залишався також аристотелізм, представлений, зокрема, Адольфом Тренделенбургом (вчителем Брентано), Густавом Тайхмюлером та Рудольфом Ойкеном (керівником докторської дисертації Макса Шелера). Крім того, такі видатні вчені, як Герман Бонітц, Карл Прантль, Герман Дільс і особливо Вернер Єгер своїми доробками істотно збагатили та своєрідно актуалізували ниву досліджень творчості Аристотеля. Епохальні твори останнього зі згаданих, безперечно, не могли не позначитися на філософській атмосфері повоєнної Німеччини, в якій формувалося мислення Гайдегера.

Втім, більшої ваги набуває той факт, що Аристотелеве вчення про час, починаючи 3 середини XIX ст., поступово стає окремим предметом в низці спеціальних розвідок, розправ і дисертацій. Залишаючи докладний розгляд цього матеріалу для іншої нагоди, варто бодай навести ці дослідження в хронологічному порядку (бібліографічний опис їх подано в переліку літератури): А. Торстік «Но́ pote ón. Щодо знайомства 3 аристотелевським мововжитком» (1857), А. Торстік «Про трактат Аристотеля про час, Phys. $\Delta$ 10sqq» (1867), Е. Готшліх «Про єдність і відмінність часу в Аристотеля» (1874), К. Шперлінг «Аристотелів погляд на психологічне значення часу, досліджений за його дефініцією часу як “числа руху” (1888), Г. Вундерлє «Вчення Аристотеля про час» (1908). Цікаво, що деякі з них не втратили своєї наукової вартості ще й досі.

Нарешті, вкрай вагомою для з'ясування спектру мотивів, що так чи так спонукали Гайдегера звернутися саме до Аристотелевого трактату про час, була праця Карла Брайга «Про буття. Абрис онтології» (1896). В цій книжці не лише подані «розлогі місця $з$ текстів Аристотеля, Томи Аквінського й Суареса, крім того етимологія слів для онтологічних основних понять», як згодом відзначав сам Гайдегер [Heidegger, 2007: S. 93]. У §§18-21 Брайг досить змістовно трактує про спосіб буття часовості, наводить різні визначення поняття часу, вказує на психологічне джерело цього поняття, викладає усвідомлення феномена часу у філософії, але - наголошуючи саме на онтологічному значенні поняття часу. При цьому він наводить розлогі цитати 3 «Фізики» Аристотеля [Braig, 1896: S. 89] і вельми стисло відтворює головні тези Аристотелевого розуміння часу, прагнучи їх інколи проілюструвати [Ibid., S. 85-86]. Поза сумнівом, ця праця фрайбурзького теолога спрямувала увагу молодого філософа на онтологічний вимір темпоральної проблематики та, що не менш важливо, на значущість для неї позиції саме Аристотеля.

У «Бутті і часі», при з’ясуванні генези звичайного розуміння часу (§81), Гайдегер не лише тлумачить Аристотелів аналіз часу, а й прямо заявляє: «Перше передане, тематично докладне тлумачення звичайного розуміння часу міститься у “Фізиці" Аристотеля...» [Heidegger, 1993: S. 428]. Згодом, уже після так званого «повороту», філософ емфатично наголошуватиме: «Аристотелівська “Фізика” є прихованою й тому ніколи достатньо не продуманою засадничою книгою (Grundbuch) західноєвропейської філософіï» [Heidegger, 1976: S. 242]. Але одразу після публікації «Буття і часу», влітку 1927 р., працюючи, мабуть, над запланованою другою частиною 
«Буття і часу» [Heidegger, 1993, S. 40], він знову звертається до Аристотелевого трактату про час і детально його інтерпретує [Heidegger, 1975: S. 330-361]. (Зауважимо, що ця інтерпретація була оприлюднена лише в 1975 р.)

Гайдегер методично продумав своє тлумачення, що вирізняється когерентністю $\mathrm{i}$ консеквентністю. Звісно, така його особливість зумовлює й оцінку дослідниками цієї інтерпретації. Наприклад, В. Броган вказує лише на ті місця в тлумаченні Гайдегера, в яких виявляється «тісна феноменологічна спорідненість» між Гайдегером і Аристотелем [Brogan, 2007: S. 97, 106]. Тому в подальшому доводиться обмежитися лише кількома штрихами, які мають увиразнити його характерні особливості. Такий підхід певною мірою корелюватиме з методологічною настановою самого Гайдегера, коли він зазначає: «При цьому ми строго не дотримуватимемося тексту [Аристотеля - B.T.], а здебільше у вільному викладі й іноді в далекосяжній інтерпретації спробуємо наблизити феномен [часу - B.T.], як його бачить Аристотель» [Heidegger, 1975: S. 336].

Інтерпретатор виходить із того, що базовим феноменом і головним предметом прояснення для Аристотелевого аналізу часу постає момент «тепер». Це добре засвідчено текстом самого Стагірита: вже при розгортанні апорій щодо природи часу цей момент часу виявляється визначальним, позаяк мовиться навіть про буття чи небуття «тепер»; сама ж тематизація часу, як випливає із вище наведеного систематичного огляду, значною мірою зосереджена на «тепер» як єдино приступному феномені; нарешті, «тепер» мовчазно припускається в дефініції часу як «числа руху відносно передшого і наступного». Іншою проблемним комплексом, на якому зосереджується увага Гайдегера, є формула дефініції часу, ії окремі елементи та іiї предметний зміст. Інші сюжети інтерпретації або залишаються на маргінесі, або випереджені систематичним задумом фундаментальної онтології.

Спираючись на тезу Аристотеля про тісний зв'язок часу і руху, Гайдегер небезпідставно виокремлює «прикметну структуру руху», формулою якої є «від чогось до чогось». 3 огляду на різноманітність видів руху наголошується, що ця структура має суто формальний характер для всіх цих видів. Кожен із них, однак, відбувається у певному вимірі, скажімо, рух як просторове переміщення відбувається у вигляді переходу від одного місця до іншого. Тому поняття виміру (Dimension), 3 яким ідентифікується протяжність чи «величина» руху, можна вважати, за Гайдегером, конкретизацією цієї структури. Проте це поняття не є засадничним, позаяк воно можливе лише через поняття «розтягання» (Dehnung) і $є$ його «певною модифікацією». Подальший рух інтерпретації виявляє, що і «вимір», і «поширення» (Erstreckung) і особливо безперервність (континуальність), якою послуговувався Аристотель у своєму аналізі часу (synechés), постають певними видозмінами ключового поняття «розтягання», що уможливлює інші феноменальні вияви руху. [Heidegger, 1975: S. 343-344]. Такий інтерпретаційний поступ цілком обгрунтований, адже він підриває поширене уявлення про час як багатоманітність дискретних точок «тепер». Натомість акцент робиться якраз на внутрішній зв'язності часу, що конкретизовано в наступній структурі.

Рухоме суще, за Гайдегером, вирізняється структурою: «звідси - туди» (her-von hin-zu) або «звідти - сюди» (von dort her - hier her). При цьому вагомими є два моменти. 3 одного боку, те, що рух рухомого - це перехід від однієї точки руху до іншої, від цієї до ще іншої і т.д. Для нашого ж сприйняття цей перехід рухомого «від - до» стає раптовою зміною чи «переміною» (Umschlag). 3 іншого боку, певні точки, які пробі- 
гає рухоме суще, утворюють тяглий, неперервний взаємозв'язок. При цьому значення має як сама безперервність, так і те, що вона «водночас переривається і не залишається тотожною» [Brogan, 2007: S. 102]. 3 суб'єктивного погляду сприйняття переходу як певного цілого можливе лише як зв'язування «вже-не» із «ще-не», що, безперечно, передбачає включеність цих елементів у ширший горизонт. У цьому контексті інтерпретатор каже: «Утримуючи попереднє, очікуючи наступне, ми бачимо перехід як такий» [Heidegger, 1975: S. 347]. Нескладно помітити, що акцент тут знову зроблено на нашому досвіді феноменально даного (рухомого) сущого, хоча Гайдегеру не можна відмовити в тому, що тематично йдеться все ж про розширене тлумачення Аристотелевої дефініції часу. Завдяки обом тим структурам робиться спроба показати, що час для Аристотеля має транзитивний характер, посутньо є «переходом».

Дефініція часу як «числа руху відносно передшого і наступного» (11, 219b1-2) теж піддається феноменологічному «висвітленню». Хоча Гайдегер виходить із неї [Ibid., S. 337] і поступово розкриває слухачам (йдеться-бо про лекційний курс) іiі зміст [Ibid., S. 341-342, 348-351], тлумачення цього пасажу є вкрай показовим для його підходу. 3 одного боку, він цілком підставно вказує тут на двозначність «próteron - hýsteron»: у просторовому значенні (точніше, в «топічному» значенні послідовності місць (11, 219a14-15), як «перед - після» і в часовому значенні «раніше пізніше» [Ibid., S. 341, 349]. Водночас він визнає, що Аристотель аналізує значення цієї пари понять у своїй «Метафізиці» (V 11, 1018b 9-1019a14), де виокремлений цілий спектр ії значень, причому темпоральне значення займає дуже скромне місце [докладніше див: Терлецький, 2013]. 3 іншого ж боку, Гайдегер уважає, що Аристотель тут у «Фізиці» «коливається в розумінні значення próteron - hýsteron» [Ibid., S. 349], віддаючи перевагу у своїй інтерпретації саме часовому визначенню «раніше - пізніше». Це цілком узгоджується 3 його феноменологічною позицією, яка полягає в тлумаченні феномена часу на підставі початковішого часу або часовості. В цьому контексті він твердить: «Тому не необхідно перекладати próteron - hýsteron в Аристотелевій дефініції часу через індиферентне «перед - після» - хоча це і має певну свою предметну виправданість, - щоб менше виявлявся іiї часовий характер, аби уникнути позірності, ніби Аристотель визначає час у звертанні до часу. Якщо сутність часу певною мірою розуміють, то Аристотелеву інтерпретацію й дефініцію часу слід інтерпретувати домірно до ії зав'язку так, щоб у ній те, що він сприймає як час, тлумачилося із часу» [Ibid., S. 341-342]. Зрештою, слід визнати, що темпоральна інтерпретація próteron - hýsteron добре відповідає систематичній інтенції Гайдегера, а саме розкриттю часовості як початкового часу, в якому коріниться «звичайне перед-наукове розуміння часу», що зафіксовано було вже Стагіритом [Ibid., S. 362].

Утім, у своїй інтерпретації Аристотелевого вчення про час Гайдегер дає зрозуміти, що йому не йдеться про те, щоб запропонувати чергове «безстороннє» витлумачення думки античного філософа. Навпаки, виходячи зі своєї концепції «екстатичності» часу, він намагається обмислити думку Аристотеля й ставить йому низку питань, зокрема, про існування часу, про його специфічний спосіб буття, про сенс «буття-в-часі». Такі питання залишилися певними дороговказами для дослідників, які працюють у рамцях феноменологічної традиції.

Одним із перших, хто сприйняв імпульси від Гайдегерового прочитання-тлумачення Аристотеля, став його учень Вальтер Брьокер (1902-1992), один зі слухачів його курсу лекцій літнього семестру 1922 р. «Феноменологічна інтерпретація вибраних трактатів Аристотеля з онтології й логіки» [Heidegger, 2005: S. 422]. У своїй 
габілітаційній дисертації, оприлюдненій 1935 року під скромним заголовком «Аристотель», він прямо визнає: «Автор [sc. Брьокер] одержав спонуку для цих розвідок завдяки дослідженням свого вчителя Гайдегера про “Буття і час"» [Bröcker, 1987: S. 5]. При висвітленні філософії Аристотеля, що виконується на дещо несподіваному грунті феномена руху (починаючи від визначення філософії, через проблематику фізики і метафізики, психології й логіки, аж до теології Стагірита), в третій главі «Рух і час» автор звертається до з'ясування зв'язку між часом і рухом [Ibid., S. 88-109]. Зазначимо, що перед нами не лише послідовна, близька до тексту інтерпретація трактату Аристотеля, але й спроба аналітично чіткої реконструкції аргументів та доказів філософа. Особливо це стосується тих пасажів, що викладені вкрай лапідарно.

У структурному та й змістовному планах розвідка Брьокера цілком звична для тлумачень такого роду. У відповідних параграфах він крок за кроком простежує хід думки Аристотеля, спершу звертається до темпоральної проблематики у звичайному перед-філософському мисленні, а також у попередній філософській традиції, згадуваній самим Стагіритом [Ibid., S. 89-92], далі - виявляє специфічний зв'язок між часом і рухом, згодом переходить до визначення сутності часу, потім зосереджується на взаємозв'язку між часом і «тепер», а насамкінець торкається сенсу мови про «буття-в-часі». Оригінальність розвідки можна вбачати в тому, що, крім відзначеного вище намагання виокремити аргументи й докази, автор пропонує деякі інтерпретаторські новації.

Як і Гайдегер, Брьокер зауважує відзначену самим Аристотелем структуру руху, точніше структурну особливість рухомого, «від чогось до чогось», однак не надає їй такого ж значення, як його вчитель. При дослідженні безперервності часу виявляється, що лише переміщення (зміна місця) як різновид руху може гарантувати таку континуальність, позаяк тільки цей рух вирізняється тим, що має характер траєкторії (die Bahn). Тут не тільки завжди наявна цілісна багатоманітність фаз рухомого, а вона завжди зберігається упродовж руху. «Шлях цього руху - це наявна траєкторія». Водночас ця траєкторія в кожному своєму відтинку є подільною до нескінченності. А оскільки «кожній точці траєкторії відповідає певна точка фази руху, а кожній точці фази відповідає певна часова точка», то з цього, за Брьокером, можна зробити висновок: «...із безперервності траєкторії випливає безперервність часу» [Ibid., S.95]. Такий характер траєкторії переміщення сущого вагомий i для розуміння чіткого порядку послідовності «передшого» і «пізнішого», що постає умовою для пізнання часу шляхом визначення в русі «передшого» $\mathrm{i}$ «пізнішого».

При тлумаченні сутності часу Брьокер виходить із Аристотелевої дефініції часу як «числа руху відносно його передшого і наступного», виокремлює в будь-якому русі як «безперервній багатоманітності часових точок» момент властивого йому тривання, окреслює час як «число тривання» відповідного руху, тобто як величину (скільки) тривання. Як наголошує дослідник, «аристотелівська дефініція часу $є$ дефініцією «як довго» [Ibid., S. 98], тобто квантитативною дефініцією. При цьому чимала увага приділяється проблемі одночасності, закарбованої Аристотелем в словах «час рівномірно усюди й при всьому» $(10,218 \mathrm{~b} 13)$. Універсальність часу, як універсальність будь-якого моменту «тепер», обгрунтовується на підставі того, що рух, який відбувається в даний теперішній момент, є єдиним. Проте Брьокер іде далі у своїй інтерпретації та стверджує: «Рух душі обгрунтовує ...універсальність часу на грунті іiї можливості універсального збігання з будь-яким сущим» [Ibid., S. 101]. При цьому мається на увазі той порух душі, який здійснюється при численні того, що 
підлягає численню. Звісно, у такому підході не складно помітити «філософський анахронізм», який полягає в запровадженні «психологічної єдності до фізичного часу Аристотеля» [Callahan, 1948: p. 65]. Складніше в цьому угледіти посутньо феноменологічне тлумачення того стану справ, що сприймання часу так чи так опосередковується свідомістю (душею) і таке опосередкування не може бути «вилучено за дужки» навіть при розгляді світового часу (рух неба).

При аналізі значення того, що має на увазі вислів «буття-в-часі», Брьокер слушно зауважує, що це питання стосується не «самих часових структур, а речей», причому «в-часі» для Аристотеля означає те ж саме, що й «у-числі», а саме: охопленість меншого більшим, що й дає змогу вимірювати суще як за часом, так і за числом. Бути в часі означає для Аристотеля «можливість вимірюватися часом» і нічого більшого [Bröcker, 1987: S. 108-109]. Із цим сюжетом тлумачення пов'язаний вагомий висновок розглядуваної інтерпретації: рух виявляється початковішим за час, а цей останній «насамперед виникає із подвійного руху неба й нашого числення» [Ibid., S. 108-109]. Таким чином, Брьокер вважає засаднично визначальним не час у його трактуванні Аристотелем, а саме феномен руху, й у цьому пункті його інтерпретація суттєво відрізняється від тлумачення його вчителя Гайдегера.

Досить неординарний виклад Брьокера не залишився поза увагою дослідників античної філософської думки. Так, цитований вище Джон Френсис Калаган неодноразово полемізує з його тезами, зокрема, дорікає за «неправильне розуміння ходу доказу Аристотеля» [Callahan, 1948: p. 46-47], коли німецький філософ з'ясовує співвідношення часу й руху та підкреслює «відмітну функцію» (по)руху наших уявлень для досвіду руху [Bröcker, 1987: S. 93]. Утім, близькі до феноменологічногерменевтичної традиції дослідники переконані, що розвідка Брьокера $\epsilon$ «все ще неодмінною книжкою для розуміння Аристотеля» [Volkmann, 1979: S. 14].

Близьким до Гайдегера за онтологічною спрямованістю думки був і Гусерлів асистент Ойген Фінк (1905-1975), що поступово проторував власний шлях у філософії, орієнтирами для якого постали «буття і світ». Постійно рефлектуючи над феноменом світу й стосунком людини до світу, Фінк звертається до витоків дослідження проблеми світу в античній метафізиці, починаючи від досократиків і закінчуючи Аристотелем. У контексті такої оригінальної онтологічної програми він і трактує Стагіритове розуміння часу, причому акцент зроблений на «випрацювані світового сенсу простору, часу й руху» [Fink, 1957: S. 10].

Інтерпретація Фінком теорії часу Аристотеля становить елегантний, пластичний виклад кроків думки грецького філософа, виклад, в якому суміщаються прискіпливість до самої думки й водночас певна відстороненість від інтерпретованого тексту. Не в останню чергу така жвавість оповіді зумовлена й тим, що в основі викладу лежить курс лекцій 1951 р. Оригінальність цього тлумачення значною мірою криється у філософській позиції його автора, тож не дивно, що онтологічна проблематика неодноразово увиразнюється разом із тематикою світу. Втім, сам текст рясніє іншими, не менш прикметними особливостями: влучними характеристиками, точними дефініціями, належними дистинкціями, доречними поняттєвими новотворами. Іноді його вкрай складно перекласти, що засвідчує вибагливість автора до мови як власного, так і витлумачуваного тексту.

Певна річ, у своєму тлумаченні Фінк пропонує покрокову реконструкцію Аристотелевого трактату. Підкреслюючи «диференційовану апоретику» міркувань про природу часу, які торкаються питань про буття чи небуття часу, двозначності моменту 
«тепер», оцінки поглядів попередників на час, Фінк показує, що «засадничим кістяком аристотелівської інтерпретації часу» постає «зв'язок заснування» (Fundierungszusammenhang): величина - pyx - час [Ibid., S. 225-226]. Лише на підставі цього є змога осмислено говорити про безперервність (континуальність), тобто зв'язність плину часу, який приступний нам тільки як «тепер». Цей «зв'язок заснування», як відзначає Фінк, далі використовується і для прояснення значення «буття-в», тобто «у величині», «y русі» та «в часі» [Ibid., S. 228], що знов-таки вагомо для з'ясування змісту того, що має на увазі Аристотель, коли мовить про «буття в числі» та «буття в часі».

Вартим уваги є й такий сюжет інтерпретації Фінка, який можна розцінювати як «заочну відповідь» з боку феноменології на поширене кривотлумачення Аристотелевої думки, мовляв, при з'ясуванні взаємозв'язку між рухом і часом він перестрибує від аналізу самого часу до сприйняття часу. Аристотель твердить на користь такого зв'язку: «Коли ж ми не здійснюємо жодної зміни в нашому мисленні або не помічаємо, що здійснили таку зміну, тоді нам здається, що не проминуло жодного часу» $(11,218 \mathrm{~b} 22-23)$. Спершу уточнюючи, Фінк додає, що «сприймання часу передбачає... принаймні рух сприймальної душі». Далі ж аргумент розгортається: «саме помічання часу $є$ певним рухом у часі, який може виявлятися як щось у русі» [Ibid., S. 225]. Більшої ваги має пластична інтерпретація пасажу про співвіднесення душі й часу $(14,223 a 16-29)$. Відхиляючи «пасивне» ставлення душі при сприйнятті часу, а воднораз і можливість «продуктивного» розуміння, ніби душа створює час, Фінк слушно зауважує: «але вона, зрештою, все ж щось виразно виявляє: а саме число моментів “тепер"». Звичайно, душа не творить «раніше» й «пізніше», бо знаходить їх у русі рухомого сущого. Але вона «спричиняє виокремлення “скільки”, виокремлення числа по відношенню до ранішого і пізнішого. Через числення душі “виникає” час» [Ibid., S. 231]. Вочевидь, маємо досить субтильне витлумачення не простої для пояснення тези Аристотеля.

Не позбавлені інтересу для дослідників і термінологічні спостереження Фінка. Він слушно відзначає, що «próteron - hýsteron», як елементи Аристотелевої дефініції часу, кепсько перекладати як «раніше - пізніше», бо в такий спосіб цим висловам надається темпоральний сенс, якого вони початково не мають у Стагірита. Знову покликаючись на згаданий «зв'язок заснування», Фінк показує, що ці елементи набувають часового нюансу лише «в русі» такого заснування: від величини - через рух - до часу. Причому, «засаднича зорієнтованість на примат простору» й тут дається взнаки, оскільки вони початково пов'язані з просторовим, тим, що містить величину [Ibid., S. 226]. У цьому пункті, до речі, особливо помітна різниця настанов Фінка й Гайдегера: хоча обидва визнають наявність часового й не-часового значень висловів, але перший виходить із початковості простору, тоді як другий намагається показати, що їхнім джерелом є початковий час.

При характеристиці двоїстої природи часу, відповідно, «тепер» (як єдиного й інакшого), Аристотель використовує термінологічне розрізнення «hó pote òn» $\mathrm{i}$ «ousía» (11, 219a20-21 et al). Фінк лише у вигляді «натяку» пропонує таке стисле пояснення: «hó pote òn - це “те, що́ є щоразу”, має характер бути у відповідний час [des Jeweiligen] y cпосіб “загальності”, a ousía означає певне буття чогось неповторно визначеного. Тепер ... як щоразу завжди дане є “тим самим”; завжди є тепер і тепер і тепер; але як певне “Тепер” воно є відповідно іншим» [Ibid., S. 227].

Як зазначалося вище, тематика «буття і світу» була однією з центральних у творчості Фінка, тож і не дивно, що вона по-своєму просвічується в його інтерпретації. 
Так, він відзначає вражаючу «близькість аристотелівського мислення до світу» [Ibid., S. 220]. Вона також виявляється в аналізі грецьким філософом простору, що мислиться як «крайня, спокійна межа вмістища світу», і при аналітиці часу, коли він критикує думку попередників, мовляв, час - це «рух цілого», себто обертання неба (10, 218a33-b2), а ще більше - в тезі про структуру часу як «охоплення» (das Umfassen), де час як число охоплює все суще, що є в ньому [Ibid., S. 230]. Щоправда, як підсумовує дослідник, «часова проблема світу», тобто проблема існування в часі світу як цілого, залишилася поза увагою Аристотеля [Ibid., S. 232]. Крім того, часова проблематика в Аристотеля тісно переплітається 3 онтологічною, що особливо помітно в зачиновому питанні, чи є час чимось сущим, чи, радше, несущим. Фінк вдало зауважує до цього, що, з одного боку, «є» (буття, сутність) зважується на підставі часу, a, з іншого боку, «у продумуванні часу в буття входить засадниче розрізнення, воно артикулюється в бутті-в-часі та бутmі-поза-часом» [Ibid., S. 222]. Зрештою, навіть результат Аристотелевого тлумачення часу має онтологічний вимір: «все рухливе, тобто все рухоме, а також супокійне, наскільки воно має можливість до руху, принципово є «сущее в часі», що становить «онтологічну конституцію physeî ónta» [Ibid., S. 229]. Як переконливо показує інтерпретатор, саме завдяки онтологічному опрацюванню часу Аристотелів аналіз «назавжди є блискучим витвором (Glanzstück) філософії».

Інтерес до часової проблематики, пожвавлений філософією життя, феноменологією та екзистенційною філософією, не вщухав також у філософській герменевтиці Г.-Г. Гадамера, що присвятив не одну розвідку з'ясуванню «загадки часу». Хоча він спеціально і не займався Аристотелевою теорією часу, вважаючи, що «його [Аристотеля] аналіз часу посутньо не відрізняється від того, що мають на думці метафори Платонового “Тімею”» [Gadamer, 1987: S. 126], однак при цьому він високо поціновував судження Аристотетя про те, що людина є тією живою істотою, яка має «чуття часу» (De anima, III, 433b7) [Gadamer, 1987: S. 139-140]. А проте, один із учнів Гадамера ляйпцизького періоду, філософ і філолог Карл-Гайнц Фольман-Шлюк (1914-1981), який досліджував античні витоки західноєвропейської онтології й метафізики, звернувся до тлумачення Аристотелевого вчення про час у контексті послідовно здійсненої ним реконструкції Стагіритової метафізики.

Фольман-Шлюк висвітлює «головні моменти» аналізу часу грецького мислителя в рамцях того, що він називає «онтологічною метафізикою» Аристотеля: царина природи тут утворює вихідний пункт, далі відбувається переступання обширу чуттєво-природного та, зрештою, погляд скеровується на надчуттєве, у царину божественного [Volkmann, 1979: S. 29]. Підставу для такої локалізації інтерпретатор убачає в самій сутності часу, бо ж «час відбувається у своїй онтологічнометафізичній суті» [Ibid., S. 161]. Здається, в цьому пункті він підхоплює тезу Фінка, згідно з якою в Аристотеля немає виразного розділення онтологічної й феноменальної сфер [Fink, 1957: S. 205]. В кожному разі він долучається до настанови розглядуваної традиції: Аристотелева теорія часу не лише містить онтологічні імплікації, а й узагалі може бути належно зрозуміла тільки на тлі його теорії буття.

Разом з іншими представниками феноменології, Фольман-Шлюк кількома штрихами показує значущість і засадничність Аристотелевого аналізу часу для наступної філософської традиції (Кант, Гегель, Ніцше) і навіть для теорії відносності, яка, розв'язуючи проблему вимірювання часу, припускає, що «час за своєю сутністю $є$ предметом вимірювання - погляд, який обгрунтував Аристотель» [Volkmann, 1979: 
S. 160, 175]. Далі йдеться про розважливий пояснювально-тлумачний виклад ходу думки Стагірита про час, аби «у спільному [з читачем] мисленні розкрити деякі головні ідеї Аристотеля [Ibid., S. 14]. Увесь зміст трактату про час постає перед читачами у формі зв'язної, але ненав'язливої, надто непретензійної реконструкції тверджень і їх обгрунтувань філософом.

Властиво феноменологічну специфіку тлумачення Фольмана-Шлюка не так просто виявити, навіть попри той факт, що він був одним із співредакторів серії «Phaenomenologica». Цитоване вище поцінування розвідки Брьокера, а також використання певних його тез («зв’язок заснування руху й часу») може слугувати певним натяком у цьому напряму. Але, на наш погляд, така специфіка найяскравіше виявляється в самому способі викладу думки Аристотеля. Так, наприклад, зачинова теза трактату про час, себто питання про сутність часу, есплікується в питомо феноменологічний спосіб: «Питання, що він, час, $\epsilon$, наперед сприймає час як щось якимось чином суще й опитує (befragt) його з огляду на те, через що він $є$ саме цим сущим, яким він $є$. Але це що́-буття (Wassein) [тобто сутність - B.T.], яке обмежовує час ним самим, не можна встановити на підставі якихось уявлень про нього, а має братися з того, що́ він $\epsilon$ і як він сам собою подає себе із самого себе» [Ibid., S. 161]. Вочевидь, у цьому описі складно не помітити близькості до Гайдегерової характеристики «феномена» в «Бутті i часі» [Heidegger, 1993: S. 31], як і загалом - що ще вагоміше - до спільної для феноменологів настанови пояснювати і розуміти феномени (зокрема, часу), виходячи iз них самих. Така настанова щораз засвідчується в традиції феноменологічної інтерпретації Стагиритового вчення про час. Інший приклад: зафіксований Аристотелем тісний зв'язок між часом і рухом докладніше тлумачиться як «приналежна до самого його [часу - B.T.] буття віднесеність до руху, яка ...має бути спершу вивільнена й визначена» [Volkmann, 1979: S. 163]. Мабуть, ще більше та специфіка виявляється в орудуванні своєрідним поняттєвим інструментарієм. Наприклад, переміщення схарактеризовано як «просторова розтягнутість (Gedehntheit) (пор. вище Гайдегерове поняття «розтягання») звідси-туди» [Ibid., S. 164]; з іншого боку, йдеться про «присутність (Anwesenheit) рухомого» сущого [Ibid., S. 169] або число руху називається “як довго” його присутності» [Ibid., S. 181]; нарешті, в контексті проблематичного зв’язку між часом і душею мовиться про неодмінність «обчислювальної душі» для того, аби час «досягав присутності (Präsenz) своєї сутності» чи навіть досягав «явності (Offenbarkeit) самого себе як часу» [Ibid., S. 186]. Такі, на позір непоказні нюанси дають підстави вважати, що інтерпретація Фолькмана-Шлюка є однією з тих, яка виписана в дусі феноменологічного прочитання Аристотеля.

В останні десятиліття також з'явилися розвідки, що написані в ключі цієї традиції й торкаються розглядуваної тут теми. Відомий сучасний феноменолог Клаус Гельд (*1936) розкриває Аристотелеву теорію часу з огляду на не вповні тематизовану в ній пітагорійську складову, яка проступає в дефініції часу як «числа руху відносно передшого і наступного» [Held, 1992: S. 15-22]. Насамперед слушно вказано на те, що тільки «душа» виявляє час, коли вона звертає увагу на самий рух, що відбувається в «дузі напруження переходу “від - до”»; при такому переході й виявляє себе «співвідношення полюсів руху», передшого і наступного. Прикметно, що таке співвідношення було названо грецькою математикою «lógos», що водночас означало й «мову». Рефлексія над рухом, артикуляція співвідношення «передше наступне» й мовлення про щораз відповідне «тепер» постають характерними особливостями тлумачення Гельда. 
Зазначене співвідношення утворює єдність двох елементів (передше - наступне), яка воднораз розділяє й поєднує їх. Те, що зібрано в такій єдності, посутньо має характер форми. У зв’язку з цим Гельд зауважує, що «формоутворювальне поняття чисельності чи множини (Anzahlbegriff)» було притаманне розумінню будь-якого числа «в класичній грецькій математиці», а прототип для нього був створений уже в пітагорійстві разом із тією тезою, що числити означає надавати форми, оформлювати [Ibid., S. 19]. За Гельдом, пітагорійський елемент в Аристотеля полягає у виявленні «співвідношення» між полюсами руху «від - до», а це співвідношення, тобто «lógos» в математичному сенсі, має характер пітагорійсько зрозумілого числа «два». Тому «засадничий сенс» дефініції Аристотеля означає, що «час є числом як пітагорійське початкове співвідношення “два-в-одному”, тобто два “тепер” у внутрішньому поширенні одного “тепер”» [Ibid., S. 21]. Значення «засадничості», на наш погляд, криється в тому, що думка Стагірита, яка зазвичай висвітлювана як фізикалістська теза тогочасної фізики, прояснюється тут з огляду на ширший філософський і науковий контекст і розкривається як далеко не пересічний і при цьому «близький до феномена» аналіз часу.

Як чільний представник сучасної феноменології, відомий своїми розвідками на ниві й античної філософії, Гельд інтерпретує Аристотелеве вчення про час з позиції його «феноменологічного осмислення». Втім, у цій інтерпретації, яка вирізняється своєю «предметно-систематичною» зорієнтованістю, вартим уваги є досить докладний сюжет, присвячений послідовному розроблюванню конститутивних для теорії Аристотеля понять «передше - наступне», які утворюють «часове в часі», виражають «властиво часову черговість» [Ibid., S. 16]. Вище неодноразово відзначалося, яку вагу надають інтерпретатори належному тлумаченню зазначених понять. I це не дивно, адже в дефініції останні постають справжнім definiens. Зрозуміло, що вони не можуть мати часового значення, позаяк це утворювало б небезпеку логічного кола в дефініції. Крім того, в самого Аристотеля «передше - пізніше» часто мають логічне значення (наприклад, у доказі засновки є «передшими» щодо висновків), але, як доречно зауважує Гельд, такий логічний зміст не релевантний для дефініції часу. Тому залишається припускати, що їхнє часове значення - вони ж бо входять у визначення часу й стають причетними до нього - має бути поступово з'ясовано. Цілком у дусі феноменології Гельд твердить: «Має бути можливо тлумачити “передше і наступне” в якомусь нечасовому сенсі, але так, щоби з цього нечасового сенсу ставало зрозумілим і часове значення, що, поза сумнівом, передбачається в дефініціï» [Ibid., S. 17]. Такий перехід від нечасового в переміщенні до часового значення «передшого - наступного» здійснюється, за Гельдом, шляхом «рафінованої абстракціï» [Ibid., S. 17]. Ї̈̈ суть в тому, що в ній спершу видобувається нечасове «передше» і «наступне» в русі, яке постає певною черговістю місць руху (він відбувається від одного місця як передшого до другого як наступного); потім, через перенесення уваги з рухомого сущого на саме рухання як процес, ми дістаємо можливість «бачити» крайні точки руху як «полюси», існування яких зумовлене самою «дугою напруження переходу від - до», тобто перебуває в постійній динаміці рухання. Часовий же сенс «передшого і наступного» розкривається лише 3 того, що така «дуга напруження» розуміється на підставі «їх перехідності» [Ibid., S. 18].

Цій інтерпретації Гельда, виконаній на феноменологічному підгрунті, не відмовиш, певна річ, в оригінальності, але вкрай вагомим $є$ те, що вона докладно зупиняється на цьому не зовсім ясному в тексті Стагірита пункті його теорії. 
Якщо Гельдова розвідка певною мірою є історико-філософською (ре)конструкцією пітагорійського елементу в античному розумінні часу (від Платона через Аристотеля до Августина), то дослідження Гюнтера Фігаля (*1949), відомого фахівця з філософії Гайдегера, систематично й зосереджено побудоване на співвідношенні тотожності моменту «тепер» і природи часу. Як визнає сам автор, йому йдеться не про «докладну інтерпретацію Аристотелевої Фізики» [Figal, 1992: S. 46], позаяк багато тем і сюжетів Аристотелевої теорії тут взагалі не згадано, а про таке висвітлення проблематичного зв'язку, яким поєднується досвід датування (тепер) із досвідом індикації (тотожного). Результат цього глибокодумного дослідження зводиться до того, що в цій теорії час виявляється приналежним до тотожності на тій підставі, що «тепер» виконує обмежувальну й тим самим визначальну роль при сприйманні часу. Звісно, такий результат може видаватися фрагментарним, однак він уповні осмислений, якщо пам'ятати про цілісний контекст розробки та розмежування концепцій часу Аристотеля й Платона.

Належність цього дослідження до розглядуваної традиції не обмежується лише тим, що його автор долучається до Гайдегера, за яким Аристотелів трактат про час закарбував усю наступну філософію часу [Ibid., S. 37-38]. Як інші представники традиції, він крок за кроком простежує досліджуваний зв'язок, експлікує тези Аристотеля й намагається так їх викласти, щоб у результаті тлумачення хід думки грецького філософа поставав консеквентним і когерентним. У плані феноменології показовою є влучна й стисла характеристика Фігалєм «числа» через визначеність множини: число означає «зрозумілість різноманітного, бо ж там, де обчислюють різноманітне й утримують [його] як численність [Anzahl], воно має визначеність певної множини» [Ibid., S. 43]. Така характеристика дає змогу пояснити дефініцію Аристотеля таким чином, що час $є$ «зрозумілістю руху відносно визначеності його передшого - наступного», а це у свою чергу означає, що цю визначеність рух не має в самому собі, а вона надається йому «визначальним і єднальним докупи «тепер» [Ibid., S. 44]. На підставі такого роз'яснення інтерпретатор висуває тезу, що «тепер» не належить часові, а останній «утворюється через подвійне “тепер”» [Ibid.]. Хоча ця теза досить контроверсійна з огляду на відповідний пасаж Стагірита, де зазначається, що без часу немає й «тепер», як і без «тепер» немає часу (219b 33sqq), варто зауважити, що німецький дослідник витончено обгрунтовує іiі з покликанням на свою засадничу тезу про обмежувальну роль подвійного «тепер».

Систематично зорієнтована розвідка Фігаля інспірує непросте питання про характер тлумачення філософського тексту минулого: має йтися про прецизне, філологічно вивірене прочитання тексту чи все ж про «систематичну реконструкцію» контексту думки автора та кроків іiі розгортання. В іншому своєму дослідженні, присвяченому критичному розглядові інтерпретації Аристотеля, запропонованої Р. Брагом (*1947) (до речі, теж на підставі феноменології, точніше, ранньої філософії Гайдегера), Фігаль схиляється до другої відповіді, позаяк тільки вона дає змогу дійти до розуміння тексту й артикулювати це розуміння [Figal, 1991]. А проте, у вказаній дилемі можлива й інша опція: інтегрувати певним чином витлумачений текст у ширший систематичний контекст опрацьовування певної тематики. Можливість цього переконливо демонструє Гельд, використовуючи Аристотелеву (разом із Платоновою) концепцію часу для увиразнення розвитку темпоральної проблематики в пізній феноменології Гусерля та в Гайдегеровому «мисленні буття» [Held, 2007: S. 329-331]. 
Як видно, мотиви звертання до Аристотелевого доробку були й залишаються щораз різними: іманентно систематичними (Гайдегер, Фігаль), історико-систематичними, (Брьокер), продиктованими відповідними предметами дослідження (Фінк, Фолькман-Шлюк) або ж cum grano salis історико-філософськими (Гельд). Попри таку строкатість підходів, все ж можна виокремити кілька типових рис феноменологічно зорієнтованої інтерпретації Аристотеля, що дає змогу відтінити розглядувану традицію від інших способів тлумачення.

Попри певну фрагментарність тексту Аристотеля, апоретичність його думки, а також - відому «застарілість» ідей та принципів «другої філософії» 3 погляду розвитку науки, представники феноменологічної традиції серйозно ставляться до його теорії часу, що продиктовано передусім філософським характером питання Аристотеля про сутність часу і його ж «феноменологічною» відповіддю на нього. Певна річ, такий інтерес до цієї теорії був викликаний вагомістю темпоральної тематики для самої феноменології, у світлі якої провадилися історичні розвідки.

На відміну від пізніх класичних і сучасних коментарів до Аристотелевої «Фізики», низка філософів, котрі ідентифікували себе 3 феноменологією, тлумачать вчення Стагирита про час не просто як один із сюжетів «другої філософії», а розглядають його як центральний і для античного розуміння часу, i для всієї наступної філософії часу.

Дотримуючись відомого гасла «назад до самих речей», репрезентанти розглядуваної традиції переконані, що єдиним предметом інтерпретації повинна бути сама лише думка Аристотеля. Різні традиції витлумачення філософа, особливо поширена в першій половині XX ст. теорія Вернера Єгера про еволюцію вчення Стагирита, розцінюються як методологічно нерелевантні проясненню як конкретних кроків аргументації, так і загальних теоретичних побудов і висновків. У такому контексті показовим $є$ той факт, що зазначені інтерпретатори, як правило, не притягують до розгляду філософські й філологічні тексти різних коментаторів і дослідників (але й не нехтують ними), ніби тримаючись іншої максими «вилучення за дужки» всього другорядного порівно з оригіналом.

Характерною ознакою такої традиції є постійне наголошення не на «що», а на «як» запропонованих інтерпретацій, що корелює з одним із методологічних принципів феноменології. Хоча в змістовному плані інтерпретації значно збігаються, за способом тлумачення і його результатами вони постають досить індивідуальними.

Постійна робота 3 оригінальним джерелом, прискіплива увага до всіх нюансів тексту, зважання на термінологічні особливості, простеження аргументації автора, послідовна реконструкція кроків думки Аристотеля (часто з урахуванням інших його творів), переведення думки Стагірита в поняттєвий контекст опрацювання часу, виявлення можливостей альтернативного прочитання певного пасажу, - усе це тією чи тією мірою присутнє у феноменологічній традиції інтерпретації. Звісно, годі сподіватися, що ми маємо справу з різновидом класичного коментарю на Аристотеля $^{4}$. Проте ми сподіваємося, що ця традиція ще здобуде належну увагу в середовищі сучасного аристотелезнавства.

\footnotetext{
${ }^{4}$ Ось як сучасний дослідник характеризує Сімплікієву манеру коментування: «Сімплікій поділяє текст Аристотеля на розділи за сенсом - спочатку на менші, потім на більші, - які він згодом коментує. Перед цим текстом він ...ставить пояснення у вигляді леми. У тексті, що поясню-
} 


\section{СПИСОК ЛІТЕРАТУРИ}

Аристотель (1981): Аристотель. «Физика». Пер. с греч. В.П. Карпова. В: Аристотель. Сочинения. В 4-х т. М.: Мысль, 1981, Т. 3, С. 59-262.

Терлецький (2013): Терлецький, В. «ТО ПРОТЕРОN. До передісторії поняття a priori». В: Sententiae, Вип. ХХІХ, 2013, № 2, С. 65-77.

Черняков (2001): Черняков, А.Г. Онтология времени. Бытие и время в философии Аристотеля, Гуссерля и Хайдеггера. Санкт-Петербург: Высшая религиозно-философская школа, 2001, $460 \mathrm{c}$.

Aristoteles (1831): Aristoteles. «Physikēs akroaseōs». In: Aristoteles Opera. Ex recensione I. Bekkeri. Berolini: Reimerum, 1831, Vol. I, P. 184-267.

Aristotle (1936): Aristotle's Physics. A revised Text with Introduction and Commentary by W.D. Ross. Oxford: Clarendon, 1936, (xii) 750 p.

Braig (1896): Braig, C. Vom Sein. Abriß der Ontologie. Freiburg: Herder, 1896, (viii) 158 S.

Bröcker (1987): Bröcker, W. Aristoteles. 5. Aufl. Frankfurt a.M.: Klostermann, 1987, 314 S.

Brogan (2007): Brogan, W. «Die Frage nach der Zeit in Heideggers Aristoteles_Interpretation. Auf dem Weg zu Sein und Zeit». In: Heidegger-Jahrbuch 3: Heidegger und Aristoteles. Hrsg. von A. Denker, G. Figal, F. Volpi, H. Zaborowski. Freiburg: Alber, 2007, S. 96-108.

Callahan (1948): Callahan, J.F. Four Views of Time in Ancient Philosophy. Cambridge: Harvard UP, 1948, $209 \mathrm{p}$.

Figal (1991): Figal, G. «Philologische Lektüre und philosophische Rekonstruktionen. Griechische Philosophie im Schatten Heideggers». In: Philosophische Rundschau, 1991, Bd. 32, H. 3, S. 201-208.

Figal (1992): Figal, G. «Zeit und Identität. Systematische Überlegungen zu Aristoteles und Platon». In: Zeiterfahrung und Personalität. Hrsg. von Forum für Philosophie Bad Homburg. Frankfurt a.M.: Suhrkamp, 1992, S. 34-56.

Fink (1957): Fink, E. Zur Ontologischen Frühgeschichte von Raum-Zeit-Bewegung. The Hague: Nijhoff, 1957, $247 \mathrm{~S}$.

Gadamer (1987): Gadamer, H.-G. Neuere Philosophie II. Probleme - Gestalten. In: Gadamer, H.G. Gesammelte Werke. Tübingen: Mohr, 1987, Bd. 4, (ix) 489 S.

Gotschlich (1874): Gotschlich, E. «Aristoteles von der Einheit und Verschiedenheit der Zeit». In: Philosophische Monatshefte, 1874, Bd. IX, H. 6, S. 285-290.

Heidegger (1975): Heidegger, M. «Die Grundprobleme der Phänomenologie». Hrsg. von F.-W. von Herrmann. In: Heidegger, M. Gesamtausgabe (GA). Frankfurt a.M.: Klostermann, 1975, Bd. 24, $473 \mathrm{~S}$.

Heidegger (1976): Heidegger, M. «Vom Wesen und Begriff der Фv́øıc. Aristoteles, Physik B, 1». In: Heidegger, M. GA. Frankfurt a.M.: Klostermann, 1976, Bd. 9, S. 239-301.

Heidegger (1993): Heidegger, M. Sein und Zeit. 17. Aufl. Tübingen: Niemeyer, 1993, (xi) $445 \mathrm{~S}$.

Heidegger (2005): Heidegger, M. «Phänomenologische Interpretation ausgewälter Abhandlungen des Aristoteles zur Ontologie und Logik». Hrsg. von G. Neumann. In: Heidegger, M. GA. Frankfurt a.M.: Klostermann, 2005, Bd. 62, (xxiii) 451 S.

\footnotetext{
ється, Сімплікій за потреби виявляє свою позицію щодо таких пунктів: упорядкування розділу в певному ході думки; місце розділу щодо попереднього; вказівка на його мету; манера і спосіб аргументації Аристотеля; виокремлення положень, що вважаються аргументами; упорядкування цих положень у силогізм (принагідно, у більш ніж одну фігуру); виявлення істинності засновків; надання засновків, що, можливо, відсутні в тексті; цитати з інших творів Аристотеля; цитати інших філософів, які підтверджують інтерпретацію; заперечення проти Аристотеля 3 боку Сімплікія або інших; протилежні закиди і спростування; інші пояснення тексту (Александра Афродісійського, почасти Темістія...); варіанти тексту, обгрунтування власного прочитання; розгортання сказаного Аристотелем з якоїсь іншої вихідної точки; питання до тексту» [Sonderegger, 1982: S. 17-18].
} 
Heidegger (2007): Heidegger, M. «Mein Weg in die Phänomenologie». In: Heidegger, M. GA. Frankfurt a.M.: Klostermann, 2007. Bd. 14, S. 91-102.

Held (1992): Held, K. «Zeit und Zahl. Der pythagoreische Zug im Zeitverständnis der Antike». In: Zeiterfahrung und Personalität, Hrsg. von Forum für Philosophie Bad Homburg. Frankfurt a.M.: Suhrkamp, 1992, S. 15-22.

Held (2007): Held, K. «Phenomenology of "Authentic Time" in Husserl and Heidegger». In: International Journal of Philosophical Studies, 2007, Vol. 15, Iss. 3, P. 327-347.

Sonderegger (1982): Sonderegger, E. Simplikios: Über die Zeit. Ein Kommentar zum Corollarium de tempore. Göttingen: Vandenhoeck \& Ruprecht, 1982, 197 S.

Sperling (1888): Sperling, K. Aristoteles' Ansicht von der psychologischen Bedeutung der Zeit untersucht an seiner Definition derselben als «Zahl der Bewegung». Marburg: UniversitätsBuchdruckerei, 1888, $73 \mathrm{~S}$.

Torstik (1857): Torstik, A. «Hó pote ón. Ein Beitrag zur Kenntnis des aristotelischen Sprachgebrauch». In: Rheinisches Museum für Philologie, NF, 1857, 12. Jg. S. 161-173.

Torstik (1867): Torstik, A. «Ueber die Abhandlung des Aristoteles von der Zeit, Phys. $\Delta$ 10ff.». In: Philologus, 1867, Bd. XXVI, S. 446-523.

Volkmann (1979): Volkmann-Schluck, K.-H. Die Metaphysik des Aristoteles. Frankfurt a.M.: Klostermann, 1979, $304 \mathrm{~S}$.

Volpi (1978): Volpi, F. «Heidegger Verhältnis zu Brentanos Aristoteles-Interpretation. Die Frage nach dem Sein des Seienden». In: Zeitschrift für philosophische Forschung, 1978, Bd. 32, H. 2, S. 254-265.

Wunderle (1908): Wunderle, G. «Die Lehre des Aristoteles von der Zeit». In: Philosophisches Jahrbuch, 1908, Bd. XXI, S. 34-55, 129-155.

Стаття одержана редакцією 27.08.2014

\section{REFERENCES}

Aristoteles. «Physikēs akroaseōs». In: Aristoteles Opera. Ex recensione I. Bekkeri. Berolini: Reimerum, 1831, Vol. I, P. 184-267. [= Aristoteles, 1831]

Aristotle. «Physics». Translated from Greek V.P. Karpov. In: Aristotle. Works: in 4 vol. [In Russian]. Moscow: Mysl, 1981, Vol. 3, P. 59-262. [= Аристотель, 1981]

Aristotle's Physics. A revised Text with Introduction and Commentary by W.D. Ross. Oxford: Clarendon, 1936, (xii) 750 p. [= Aristotle, 1936]

Braig, C. Vom Sein. Abriß der Ontologie. Freiburg: Herder, 1896, (viii) 158 S. [= Braig, 1896]

Bröcker, W. Aristoteles. 5. Aufl. Frankfurt a.M.: Klostermann, 1987, 314 S. [= Bröcker, 1987]

Brogan, W. «Die Frage nach der Zeit in Heideggers Aristoteles Interpretation. Auf dem Weg zu Sein und Zeit». In: Heidegger-Jahrbuch 3: Heidegger und Aristoteles. Hrsg. von A. Denker, G. Figal, F. Volpi, H. Zaborowski. Freiburg: Alber, 2007, S. 96-108. [= Brogan, 2007]

Callahan, J. F. Four Views of Time in Ancient Philosophy. Cambridge: Harvard UP, 1948, 209 p. [= Callahan, 1948]

Chernakov A. The Ontology of Time. Being and Time in the Philosophies of Aristotle, Husserl and Heidegger. [In Russian]. St. Petersburg: Vysshaya Religiosno-Philosophskaya Shkola, 2001, 460 p. [= Черняков, 2001]

Figal, G. «Philologische Lektüre und philosophische Rekonstruktionen. Griechische Philosophie im Schatten Heideggers». In: Philosophische Rundschau, 1991, Bd. 32, H. 3, S. 201-208. [= Figal, 1991]

Figal, G. «Zeit und Identität. Systematische Überlegungen zu Aristoteles und Platon». In: Zeiterfahrung und Personalität, Hrsg. von Forum für Philosophie Bad Homburg. Frankfurt a.M.: Suhrkamp, 1992, S. 34-56. [= Figal, 1992]

Fink, E. Zur Ontologischen Frühgeschichte von Raum-Zeit-Bewegung. The Hague: Nijhoff, 1957, 247 S. [= Fink, 1957] 
Gadamer, H.-G. Neuere Philosophie II. Probleme - Gestalten. In: Gadamer, H.-G. Gesammelte Werke. Tübingen: Mohr, 1987, Bd. 4, (ix) 489 S. [= Gadamer, 1987]

Gotschlich, E. «Aristoteles von der Einheit und Verschiedenheit der Zeit». In: Philosophische Monatshefte, 1874, Bd. IX, H. 6, S. 285-290. [= Gotschlich, 1874]

Heidegger, M. «Die Grundprobleme der Phänomenologie». Hrsg. von F.-W. von Herrmann. In: Heidegger, M. Gesamtausgabe (GA). Frankfurt a.M.: Klostermann, 1975, Bd. 24, 473 S. [= Heidegger, 1975]

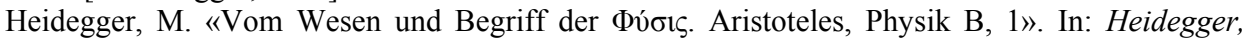
M. GA. Frankfurt a.M.: Klostermann, 1976, Bd. 9, S. 239-301. [= Heidegger, 1976]

Heidegger, M. Sein und Zeit. 17. Aufl. Tübingen: Niemeyer, 1993, XI, 445 S. [= Heidegger, 1993]

Heidegger, M. «Phänomenologische Interpretation ausgewälter Abhandlungen des Aristoteles zur Ontologie und Logik». Hrsg. von G. Neumann. In: Heidegger, M. GA. Frankfurt a.M.: Klostermann, 2005, Bd. 62, (xxiii) $451 \mathrm{~S}$. [= Heidegger, 2005]

Heidegger, M. «Mein Weg in die Phänomenologie». In: Heidegger, M. GA. Frankfurt a.M.: Klostermann, 2007. Bd. 14, S. 91-102. [= Heidegger, 2007]

Held, K. «Phenomenology of "Authentic Time" in Husserl and Heidegger». In: International Journal of Philosophical Studies, 2007, Vol. 15, Iss. 3, P. 327-347. [= Held, 2007]

Held, K. «Zeit und Zahl. Der pythagoreische Zug im Zeitverständnis der Antike». In: Zeiterfahrung und Personalität. Hrsg. von Forum für Philosophie Bad Homburg. Frankfurt a.M.: Suhrkamp, 1992, S. 15-22. [= Held, 1992]

Sonderegger, E. Simplikios: Über die Zeit. Ein Kommentar zum Corollarium de tempore. Göttingen: Vandenhoeck \& Ruprecht, 1982, 197 S. [= Sonderegger, 1982]

Sperling, K. Aristoteles' Ansicht von der psychologischen Bedeutung der Zeit untersucht an seiner Definition derselben als «Zahl der Bewegung». Marburg: Universitäts-Buchdruckerei, 1888, $73 \mathrm{~S}$. [= Sperling, 1888]

Terletsky, V. «TO PROTERON. On the Prehistory of the Concept of A priori». [In Ukrainian]. In: Sententiae, Iss. XXIX, 2013, № 2, Р. 65-77. [= Терлецький, 2013]

Torstik, A. «Hó pote ón. Ein Beitrag zur Kenntnis des aristotelischen Sprachgebrauch». In: Rheinisches Museum für Philologie, NF, 1857, 12. Jg. S. 161-173. [= Torstik, 1857]

Torstik, A. «Ueber die Abhandlung des Aristoteles von der Zeit, Phys. $\Delta$ 10ff.». In: Philologus, 1867, Bd. XXVI, S. 446-523. [= Torstik, 1867]

Volkmann-Schluck, K.-H. Die Metaphysik des Aristoteles. Frankfurt a.M.: Klostermann, 1979, 304 S. [= Volkmann, 1979]

Volpi, F. «Heidegger Verhältnis zu Brentanos Aristoteles-Interpretation. Die Frage nach dem Sein des Seienden». In: Zeitschrift für philosophische Forschung, 1978, Bd. 32, H. 2, S. 254-265. [= Volpi, 1978]

Wunderle, G. «Die Lehre des Aristoteles von der Zeit». In: Philosophisches Jahrbuch, 1908, Bd. XXI, S. 34-55, 129-155. [= Wunderle, 1908]

Received 27.08.2014

\section{Vitali Terletsky}

\section{Aristotle's Theory of Time in the Light of the Phenomenological Tradition}

The paper deals with reconstitution of tradition, whose representatives (M. Heidegger, W. Bröcker, E. Fink, K.-H. Volkmann-Schluck, K. Held, G. Figal) at any given time in their own way interpret the doctrine of time in Aristotle's «Physics» in the phenomenological resp. hermeneutic perspective. It focuses on the relation of time and change, the problems of identity and difference of «now», temporal and timeless meaning of próteron - hýsteron, the relationship of time and soul, the sense of «being-in-time» thesis. In this tradition the need for «a systematic reconstruction» of the Stagirite's arguments and examination of coherence of certain 
propositions is frequently emphasized, This is motivated, on the one hand, by the development of temporal thematic within phenomenology itself, and, on the other hand, by the dissociation from only historical or philological reading of this classical text.

Vitali Terletsky, PhD in philosophy, senior researcher at the Research Institute of Ukraine Studies

Віталій Терлецький, кандидат філософських наук, старший науковий співробітник Науково-дослідного інституту українознавства

Виталий Терлецкий, кандидат философских наук, стариий научный сотрудник Научноисследовательского института украиноведения

e-mail: terletsky.vm@gmail.com 